\title{
ANALISIS PENGARUH EVA, ROA DAN ROE TERHADAP RETURN SAHAM PADA PERUSAHAAN MANUFAKTUR DI BURSA EFEK JAKARTA TAHUN 2006-2008
}

\author{
WIKAN BUDI UTAMI \\ STIE AAS Surakarta \\ wikan.budiutami@yahoo.com
}

\begin{abstract}
ABSTRAK
Tujuan dalam penelitian ini adalah untuk mengetahui pengaruh EVA, ROA dan ROE terhadap return pemegang saham.

Sampel yang diambil dalam penelitian ini adalah perusahaan manufaktur yang terdaftar di Bursa Efek Jakarta (BEJ) yang tercantum dalam Indonesian Capital Market Directory dan internet dengan situs www.jsx.co.id sejak tahun 2006 sampai dengan 2008. Sampel penelitian ditentukan berdasarkan purposive sampling.

Dalam penelitian ini uji asumsi klasik yang digunakan adalah: uji normalitas, uji Autokorelasi, uji Multikolinearitas, uji Heterokedastisitas, Uji Regresi (Uji fdan t).

Pengujian hipotesis yang digunakan adalah uji $\mathrm{f}$, uji t dan $u j i \mathrm{R}^{2}$.

Hasil uji $F$ diperoleh nilai $F_{\text {hitung }}$ sebesar 1,226 dengan tingkat signifikansi 0,317. Karena nilai signifikansi $\mathrm{F}$ lebih besar dari 0,05 maka disimpulkan tidak ada pengaruh simultan antara variabel Economic Value Added (EVA), Return on Assets (ROA), Return on Equity (ROE) terhadap Return Saham.

Hasil uji t diperoleh variabel EVA memiliki tingkat signifikansi lebih dari 0,05 yaitu sebesar 0,100. Dengan tingkat signifikansi 0,100 yang lebih besar dari 0,05 disimpulkan bahwa secara parsial Economic Value Added (EVA) tidak berpengaruh terhadap Return Saham perusahaan. Variabel ROA memiliki tingkat signifikansi lebih besar dari 0,05 yaitu sebesar 0,789. Dengan tingkat signifikansi 0,789 lebih besar dari 0,05 disimpulkan bahwa secara parsial Return on Asset tidak berpengaruh terhadap Return Saham perusahaan. Variabel ROE memiliki tingkat signifikansi lebih dari 0,05 yaitu sebesar 0,689. Dengan tingkat signifikansi sebesar 0,689 yang lebih besar dari 0,05 disimpulkan bahwa secara parsial Return on Equity (ROE) tidak berpengaruh terhadap Return Saham perusahaan

Hasil uji koefisien determinasi diperoleh nilai $\mathrm{R}^{2}$ sebesar 0,109 atau 10,9\%. Hal ini menunjukan bahwa 10,9\% dari nilai variabel dependen yaitu Return Saham dapat dijelaskan oleh Economic Value Added (EVA), Return on Assets (ROA) dan Return on Equity (ROE) sedangkan sisa nilai variabel dependen yaitu sebesar $89,1 \%$ tidak dapat dijelaskan oleh persamaan regresi atau dipengaruhi oleh faktor lain yang tidak termasuk dalam model analisis.

Hasil penelitian ini diharapkan dapat memberi masukan bagi investor dalam melakukan invetasi saham dengan tidak hanya melihat kondisi perusahaan melalui rasio keuangan, khususnya melalui rasio EVA, ROA dan ROE tapi dengan rasio lain sebagai penentu investasi. Kata kunci: Economic Value Added (EVA), Return on Assets (ROA), Return on Equity (ROE) dan Return Saham
\end{abstract}




\section{PENDAHULUAN}

Kesuksesan suatu perusahaan
dalam mempertahankan eksistensinya tidak luput dari peran manajer keuangan dan pengaruh keputusan keuangan yang telah dilakukan. Para manajer keuangan memiliki tugas utama yaitu merencanakan pengadaan dan penggunaan guna memaksimumkan nilai perusahaaan.

Pasar modal merupakan salah satu fasilitas untuk menyalurkan dana dari lenders (pihak yang memiliki kelebihan dana) kepada borrowers (pihak yang membutuhkan dana). pasar modal merupakan salah satu fasilitas untuk menyalurkan dana dari lenders (pihak yang memiliki kelebihan dana) kepada borrowers (pihak yang membutuhkan dana). Penilaian prestasi suatu perusahaan dapat dilihat dari kemampuan perusahaan itu untuk menghasilkan laba. Laba perusahaan selain merupakan indikator kemampuan perusahaan memenuhi kewajiban bagi para penyandang dananya juga merupakan elemen dalam penciptaan nilai perusahaan yang menunjukkan prospek perusahaan di masa yang akan datang

Tingkat profitabilitas perusahaan dapat diukur dari beberapa aspek, yaitu berdasarkan ROS (Return on Sales), EPS (Earning Per Share), ROA (Return on Asset), ROE (Return on Equity). Untuk mengukur seberapa efektif perusahaan yang beroperasi sehingga menghasilkan keuntungan atau mencapai tujuan profit keseluruhan, terutama dalam hubungannya dengan sumbersumber yang diinvestasikan digunakan rasio profitabilitas yang terdiri dari ROA, dan ROE.

Tetapi penggunaan analisis rasio keuangan sebagai alat pengukur akuntansi konvensional memiliki kelemahan utama yaitu mengabaikan adanya biaya modal sehingga sulit untuk mengetahui apakah suatu perusahaan telah berhasil menciptakan nilai atau tidak. Maka agar kelemahan tersebut dapat teratasi dikembangkan suatu konsep baru yaitu EVA (Economic Value Added) atau nilai tambah ekonomis yang merupakan pendekatan baru dalam menilai kinerja perusahaan.

Pada dasarnya EVA mengukur nilai tambah dalam suatu periode tertentu. Nilai tambah ini tercipta apabila perusahaan memperoleh keuntungan (profit) di atas biaya modal (cost of capital) perusahaan. Kondisi EVA yang positif mencerminkan tingkat pengembalian yang lebih tinggi daripada tingkat biaya modal. EVA 
yang positif menunjukkan kemampuan manajemen dalam menciptakan peningkatan nilai kekayaan perusahaan / pemilik modal, dan sebaliknya.

Tujuan dalam penelitian ini adalah untuk mengetahui pengaruh EVA, ROA dan ROE terhadap return pemegang saham.

\section{LANDASAN TEORI}

Pengertian Saham

Menurut Sartono (2003) bahwa saham merupakan tanda penyertaan modal pada suatu perseroan terbatas. Dengan memiliki saham suatu perusahaan, maka manfaat yang diperoleh berupa deviden, capital gain dan manfaat non-financial. Sedangkan kalau para pemodal membeli saham, berarti mereka (investor) membeli prospek perusahaan. Bila prospek perusahaan baik maka harga saham tersebut akan meningkat, (Husnan, 1993:11). Saham merupakan bukti kepemilikan yang memberikan penghasilan yang tidak tetap karena tergantung pada mekanisme pasar.

\section{Jenis Saham}

Dari berbagai jenis saham yang dikenal di bursa, yang diperdagangkan yaitu saham biasa (common stock) dan saham preferen (preferred stock). Jika perusahaan hanya mengeluarkan satu kelas saham saja, saham ini biasanya dalam bentuk saham biasa (common stock). Pemegang saham adalah pemilik dari perusahaan yang mewakilkan kepada manajemen untuk menjalankan operasi perusahaan.

\section{Profitabilitas}

Rasio profitabilitas mengukur kemampuan perusahaan untuk menghasilkan laba. Rasio-rasio profitabilitas yang banyak digunakan adalah:

\section{a. Economic Value Added (EVA)}

EVA sebagai indikator dari keberhasilan manajemen dalam memilih dan mengelola sumbersumber dana yang ada di perusahaan tentunya juga akan berpengaruh positif terhadap return pemegang saham.

Di dalam konsep EVA memperhitungkan modal saham, sehingga memberikan pertimbangan yang adil bagi para penyandang dana perusahaan. Analis sekuritas menemukan bahwa harga saham mengikuti EVA jauh lebih dekat dibanding faktor lainnya seperti laba per saham, marjin operasi. Korelasi ini terjadi karena EVA benar-benar diperhatikan investor. Apabila nilai EVA suatu perusahaan meningkat, maka kinerja perusahaan semakin baik sehingga kesejahteraan para 
pemegang saham dapat ditingkatkan.

EVA sangat bermanfaat bagi penilai kinerja perusahaan di mana fokus penilaian kinerja adalah pada penciptaan nilai (value creation). Penilaian kinerja dengan menggunakan pendekatan EVA menyebabkan perhatian manajemen sesuai dengan kepentingan pemegang saham. Dengan EVA, para manajer akan berpikir dan juga bertindak seperti halnya pemegang saham, yaitu memilih investasi yang memaksimumkan tingkat pengembalian dan meminimumkan tingkat biaya modal sehingga nilai perusahaan dapat dimaksimumkan.

Penilaian EVA dapat dinyatakan sebagai berikut:

- Apabila EVA > 0, berarti nilai EVA positif yang menunjukkan telah terjadi

$$
R O A=\frac{\text { LabaBersih }}{\text { TotalAktiva }} \times 100 \%
$$

Semakin tinggi keuntungan yang dihasilkan perusahaan akan menjadikan investor tertarik akan nilai saham.

\section{c. Return On Equity (ROE)}

Return

merupakan

perusahaan on Equity kemampuan dalam proses nilai tambah pada perusahaan.

- $\mathrm{EVA}=0$ menunjukkan posisi impas atau Break Event Point.

- Apabila EVA < 0, yang berarti EVA negatif menunjukkan tidak terjadi proses nilai tambah.

\section{b. Return On Assets (ROA)}

Return on Assets juga sering disebut sebagai rentabilitas ekonomis merupakan ukuran kemampuan perusahaan dalam menghasilkan laba dengan semua aktiva yang dimiliki oleh perusahaan. Rasio ini menunjukan kemampuan dari modal yang diinvestasikan dalam keseluruhan aktiva untuk menghasilkan keuntungan bagi semua investor. menghasilkan keuntungan dengan modal sendiri yang dimiliki, sehingga ROE ini ada yang menyebut sebagai rentabilitas modal sendiri (Sartono:2003). Semakin besar ROE mencerminkan kemampuan perusahaan dalam 
menghasilkan keuntungan yang

$$
\text { ROE }=\frac{\text { LabaBersih }}{\text { ModalSendiri }} \times 100 \%
$$

\section{d. Return Saham}

Return merupakan hasil yang diperoleh dari sebuah investasi. Return dapat berupa return realisasi (realized return) yaitu return yang telah terjadi atau return ekspektasi (expected return) yaitu return yang diharapkan akan terjadi di masa yang akan datang. Tujuan corporate finance adalah memaksimumkan nilai perusahaan. Tujuan ini bisa menyimpan konflik potensial antara pemilik perusahaan dengan kreditur.

Saham suatu perusahaan bisa dinilai dari pengembalian (return) yang diterima oleh pemegang saham dari perusahaan yang bersangkutan. Return bagi pemegang saham bisa berupa penerimaan dividen tunai ataupun adanya perubahan harga saham pada suatu periode.

Untuk melakukan investasi dalam bentuk saham diperlukan

$$
R_{i t}=\frac{P_{i t}-P_{i t-1}}{P_{i t-1}}
$$

Keterangan:

$\mathrm{R}_{\mathrm{it}} \quad=$ Tingkat keuntungan saham i pada periode $\mathrm{t}$.

$\mathrm{P}_{\mathrm{it}} \quad=$ Harga saham $\mathrm{i}$ pada periode $\mathrm{t}$.

$\mathrm{P}_{\mathrm{it}-1} \quad=$ Harga saham sebelum periode $\mathrm{t}$. tinggi bagi pemegang saham.

analisis untuk mengukur nilai saham, yaitu analisis fundamental dan analisis teknikal. Tujuan analisis fundamental adalah menentukan apakah nilai saham berada pada posisi undervalue atau overvalue. Saham dikatakan undervalue bilamana return saham di pasar saham lebih kecil dari harga wajar atau nilai yang seharusnya, demikian juga sebaliknya. Dapat dikatakan bahwa untuk memperkirakan return saham dapat menggunakan analisa fundamental yang menganalisa kondisi keuangan dan ekonomi perusahaan yang menerbitkan saham tersebut.

Return saham dapat diukur sebagai berikut : 
Return saham merupakan pendapatan yang diterima oleh pemegang saham berupa deviden yang dibayar oleh perusahaan maupun capital gain yaitu selisih antara harga jual dan harga beli saham. (Lucky:2005)

Penelitian Terdahulu

Menurut Gary C. Biddle (1996) menyatakan bahwa pengukuran return pemegang saham dan nilai perusahaan akan lebih tinggi jika diukur dengan Economic Value Added (EVA). Tes konten informasi relatif mengungkapkan pendapatan untuk lebih terkait dengan pengembalian dan nilai-nilai perusahaan dari EVA, residual pendapatan, atau arus kas dari operasi. Incremental tes menunjukkan bahwa komponen EVA hanya menambahkan marginal informasi pendapatan di luar konten. Namun jika dihitung secara bersama, hasil ini tidak mendukung klaim bahwa penghasilan EVA relatif mendominasi isi informasi, dan menyarankan agar pendapatan yang umumnya melebihi EVA. Menurut penelitian yang dilakukan oleh Mariana Sri Rahayu (2007) EVA (Economic Value Added) tidak mempunyai pengaruh positif yang signifikan terhadap return of saham perusahaan yang termasuk dalam LQ 45 dan MVA (Market Value Added) tidak mempunyai pengaruh positif yang signifikan terhadap return of saham perusahaan yang termasuk dalam LQ 45.

Sedangkan penelitian lain (Fandi Yuniawan, 2006) menunjukkan bahwa analisa yang dilakukan secara parsial yang menunjukan bahwa variabel ROI, OCF, dan EVA berpengaruh signifikan terhadap Rate of Return, hasil tersebut sesuai dengan penelitian sebelumnya yang dilakukan oleh Miranda Octora, Yuliana Salim, Thio Anastasia Petrolina (2003 ). Hasil analisa yang diperoleh secara simultan menunjukan bahwa semua variabel yaitu ROI, ROE, OCF, dan EVA mempunyai pengaruh yang signifikan terhadap Rate of Return (ROR). Sehingga keempat indikator ini secara simultan (bersama-sama) bagi investor merupakan indikator yang penting untuk dipertimbangkan untuk mengukur kinerja perusahaan dalam rangka mengambil keputusan investasi.

Saptorini Kartika Dewi (2004) melakukan penelitian mengenai pengaruh EVA dan rasio profitabilitas yang diproksikan dengan ROE, ROI, dan EPS terhadap perubahan harga saham perusahaan manufaktur di Bursa Efek Jakarta. Hasil penelitian menunjukkan bahwa secara parsial baik EVA maupun rasio profitabilitas tidak berpengaruh terhadap perubahan harga saham. 
Sasongko dan Wulandari (2006) melakukan penelitian mengenai EVA dan rasio-rasio profitabilitas ROA, ROE, ROS, EPS, dan BEP terhadap harga saham perusahaan manufaktur di Bursa Efek Jakarta. Hasil penelitian menunjukkan bahwa secara parsial hanya EPS yang berpengaruh signifikan terhadap harga saham, sedangkan EVA, ROA, ROE, ROS, dan BEP tidak berpengaruh terhadap perubahan harga saham.

Kerangka pemikiran teoritis dalam penelitian ini dapat digambarkan sebagai berikut:

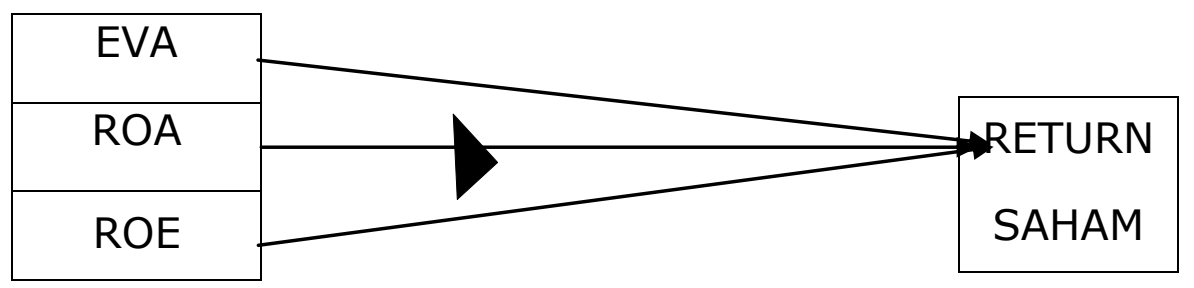

METODOLOGI PENELITIAN

\section{Objek Penelitian}

Objek yang diteliti adalah harga-harga saham tahunan dari populasi saham perusahaan manufaktur yang terdaftar dalam Bursa Efek Jakarta sejak tahun 2006 sampai dengan 2008.

\section{Sampel Penelitian}

Sampel yang diambil dalam penelitian ini adalah perusahaan manufaktur yang terdaftar di Bursa Efek Jakarta (BEJ) yang tercantum dalam Indonesian Capital Market Directory dan internet dengan situs www.jsx.co.id sejak tahun 2006 sampai dengan 2008.

Sampel penelitian ditentukan berdasarkan purposive sampling. a. Economic Value Added (EVA) Economic Value Added (EVA) sama dengan NOPAT (Net Operating Profit After Tax) yang merupakan laba operasi perusahaan setelah pajak dan mengukur laba yang diperoleh perusahaan dari operasi berjalan, dikurangi dengan biaya modal.

EVA : NOPAT - WACC $\times$ C Keterangan:

EVA : Economic Value Added, (Rp)

NOPAT : Net Operating Profit After Tax, (Rp) WACC : Weighted Average Cost of Capital C : Invested Capital, (Rp)

b. ROA (Return on Asset)

Variable Penelitian 1. Variabel Independen 
Return on asset adalah perbandingan laba tahunan tahun $t$ setelah pajak terhadap total aktiva tahun $\mathrm{t}$. ROA merupakan rasio yang menggambarkan seberapa cepat laba atau return atas investasi dalam bentuk aset perusahaan ( Brigham \& Houston,2001:96).

$$
R O E=\frac{\text { Laba Bersih Sesudah Pajak }}{\text { Total Equity }}
$$

2. Variabel Dependen

Variabel yang menjadi variabel terikat dalam penelitian ini adalah return saham. Return saham yang digunakan dalam penelitian ini adalah return saham sesungguhnya (return

( Harga Saham $\underline{t}$ - Harga Saham $\underline{t-1}$ ) Harga Saham t-1

\section{Teknik Pengumpulan Data}

Data yang akan diperoleh dari laporan keuangan yang dipublikasikan yaitu laporan keuangan tahun 2006-2008 dari perusahaan yang menjadi sampel yang diakses di Bursa Efek Jakarta (BEJ) yang tercantum dalam Indonesian Capital Market Directory dan internet dengan situs www.jsx.co.id.

\section{Alat Analisis Data}

1. Pengujian Asumsi Klasik

\section{c. ROE (Return on Equity)}

Rasio ini mengukur seberapa efektif perusahaan memanfaatkan kontribusi pemilik dan/atau seberapa efektif perusahaan menggunakan sumber sumber lain untuk kepentingan pemilik.

realisasi) karena return ini sudah terjadi dan dihitung berdasarkan data historis tahunan.

Formula untuk menghitung

return saham adalah: 
Uji autokorelasi

dimaksudkan untuk mengetahui apakah terjadi korelasi antara anggotaanggota dari serangkaian pengamatan tersusun dalam rangkaian waktu (times $D W=\frac{\sum_{t-1}^{n}(e t-e t-1) 2}{\sum_{t-1}^{n} e t 2}$

Dimana :

t : waktu

et : residual pada periode $t$

et-1 : residual npada periode $\mathrm{t}-1$

Cara untuk mendeteksi adanya Autokorelasi dalam menganalisis regresi dengan series) dan dalam rangkaian ruang (cross section). Untuk mengetahui dan menguji ada tidaknya autokorelasi dalam model analisis regresi, bisa digunakan cara pengujian statistik Durbin Watson (DW).

Tabel Autokorelasi

\begin{tabular}{|c|c|}
\hline Jenis Autokorelasi & Tingkat Autokorelasi \\
\hline Autokorelasi Negatif & DW $>2$ \\
\hline $\begin{array}{c}\text { Tidak ada } \\
\text { Autokorelasi }\end{array}$ & $-2<\mathrm{DW}<2$ \\
\hline Autokorelasi Positif & DW $<-2$ \\
\hline
\end{tabular}

Sumber: Santoso, Singgih, 2001

menggunakan DW dapat dijelaskan sebagai berikut:

e. Uji Multikolinearitas

Multikolinearitas adalah adanya hubungan yang kuat antar variabel independen dalam persamaan regresi. Adanya multikolinearitas akan mengakibatkan ketidaktepatan sehingga estimasi, kesimpulan yang menerima hipotesis nol. Hal ini menyebabkan koefisien dan standard deviasi sangat sensitif terhadap perubahan harga (Gujarati, 1995).

\section{f. Uji Heterokedastisitas} Heteroskedastisitas adalah variabel pengganggu (el) memiliki varian yang 
berbeda dari satu observasi ke observasi lainnya atau varian antar variabel independen tidak sama. Hal ini melanggar asumsi homokedastisitas yaitu setiap variabel penjelas memiliki

\section{g. Analisis Regresi}

Dalam penelitian ini digunakan analisis regresi berganda dengan persamaan kuadrat terkecil (OLS) dengan model dasar sebagai berikut: varian yang sama (konstan).

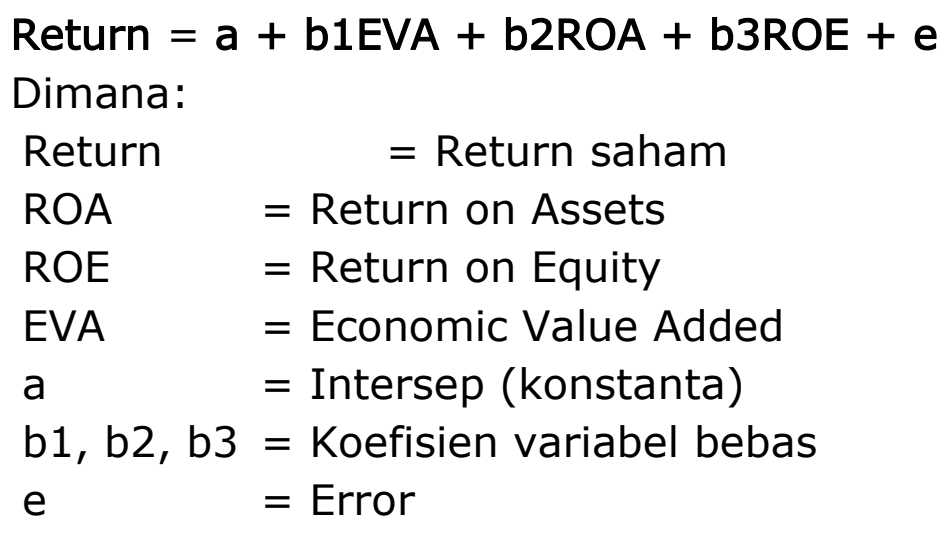

\section{Pengujian hipotesis} yang digunakan adalah uji $\mathrm{f}$, $u j i t$ dan $u j i R^{2}$. Perhitungan dilakukan dengan bantuan komputer melalui program Excel dan SPSS.

\section{1) Uji $f$}

Uji f dilakukan untuk mengetahui pengaruh variabel bebas secara bersama-sama terhadap variabel terikat.

2) Uji t

\begin{tabular}{lr}
\multicolumn{2}{r}{ Uji t pada dasarnya } \\
menunjukkan seberapa \\
jauh pengaruh & satu \\
variabel bebas & secara \\
individual & dalam \\
menerangkan & variasi \\
variabel terikat. &
\end{tabular}

Untuk mengetahui kebenaran hipotesis digunakan kriteria bila $\mathrm{t}$ hilang $>\mathrm{t}$ tabel maka Ho ditolak dan $\mathrm{Ha}$ diterima, artinya ada pengaruh antara variabel bebas terhadap variabel terikat dengan derajat keyakinan yang digunakan sebesar a $=1 \%, a=5 \%, a=10 \%$, begitu pula sebaliknya bila t dihitung $<\mathrm{t}$ tabel maka menerima Ho dan menolak $\mathrm{Ha}$ artinya tidak ada pengaruh antara variabel bebas terhadap variabel terikat. 
3) $R^{2}$ (Koefisien determinasi)

Koefisien determinasi bernilai nol berarti tidak ada hubungan antara variabel bebas dengan variabel terikat. Sebaliknya nilai koefisien determinasi 1 berarti suatu kecocokan sempurna dari ketepatan model.

\section{PEMBAHASAN}

Data sampel perusahaan akan ditampilkan secara ringkas dalam tabel berikut:

\section{Tabel 1}

Perusahaan Manufaktur yang terdaftar di Bursa Efek Jakarta periode 2006 - 2008 serta memenuhi karakteristik sebagai sampel.

\begin{tabular}{|c|l|c|l|}
\hline No & \multicolumn{1}{|c|}{ Nama Perusahaan } & No & \multicolumn{1}{|c|}{ Nama Perusahaan } \\
\hline 1 & $\begin{array}{l}\text { PT. Aqua Golden Mississippi } \\
\text { Tb }\end{array}$ & 26 & PT. Jaya Pari Steel Tbk \\
\hline 2 & PT. Delta Djakarta Tbk & 27 & PT. Lionmesh Prima Tbk \\
\hline 3 & PT. Fast Food Indonesia Tbk & 28 & PT. Lion Metal Works Tbk \\
\hline 4 & $\begin{array}{l}\text { PT. Indofood Sukses Makmur } \\
\text { Tbk }\end{array}$ & 29 & PT. Tira Austenite \\
\hline 5 & PT. Mayora Indah Tbk & 30 & $\begin{array}{l}\text { PT. Surya Toto Indonesia } \\
\text { Tbk }\end{array}$ \\
\hline 6 & PT. Tunas Baru Lampung & 31 & PT. Sumi Indo Kabel Tbk \\
\hline 7 & PT. Ultra Jaya Milk Tbk & 32 & PT. Astra Graphia Tbk \\
\hline 8 & PT. Gudang Garam Tbk & 33 & PT. Astra International Tbk \\
\hline 9 & PT. HM Sampoerna Tbk & 34 & PT. Astra Otoparts Tbk \\
\hline 10 & PT. Roda Vivatex Tbk & 35 & $\begin{array}{l}\text { PT. Hexindo Adiperkasa } \\
\text { Tbk }\end{array}$ \\
\hline 11 & PT. Indorama Sintetics Tbk & 36 & PT. Intraco Penta Tbk \\
\hline 12 & PT. Sepatu Bata Tbk & 37 & PT. Selamat Sempurna Tbk \\
\hline 13 & PT. Fajar Surya Wisesa Tbk & 38 & PT. Tunas Ridean Tbk \\
\hline 14 & PT. AKR Corporindo Tbk & 39 & PT United Tractor Tbk \\
\hline 15 & PT. Lautan Luas Tbk & 40 & $\begin{array}{l}\text { PT. Bristol-Myers Squibb } \\
\text { Indon }\end{array}$ \\
\hline 16 & $\begin{array}{l}\text { PT. Sorini Agro Asri } \\
\text { Corporind }\end{array}$ & 41 & $\begin{array}{l}\text { PT. Darya Varia Laboratoria } \\
\text { Tb }\end{array}$ \\
\hline 17 & $\begin{array}{l}\text { PT. Unggul Indah Cahaya } \\
\text { Tbk }\end{array}$ & 42 & $\begin{array}{l}\text { PT. Indofarma (persero) } \\
\text { Tbk }\end{array}$ \\
\hline & & \\
\hline
\end{tabular}




\begin{tabular}{|l|l|c|l|}
18 & $\begin{array}{l}\text { PT. Ekadharma International } \\
\text { Tb }\end{array}$ & 43 & PT. Kalbe Farma Tbk \\
\hline 19 & $\begin{array}{l}\text { PT. Argha Karya Prima } \\
\text { Industri }\end{array}$ & 44 & $\begin{array}{l}\text { PT. Kimia Farma (persero) } \\
\text { Tbk }\end{array}$ \\
\hline 20 & PT. Kageo Igar Jaya Tbk & 45 & PT. Merck Tbk \\
\hline 21 & PT. Trias Sentosa Tbk & 46 & PT. Pyridam Farma Tbk \\
\hline 22 & $\begin{array}{l}\text { PT. Indocement Tunggal } \\
\text { Prakars }\end{array}$ & 47 & PT. Tempo Scan Pasifik Tbk \\
\hline 23 & $\begin{array}{l}\text { PT. Semen Gresik (persero) } \\
\text { Ind }\end{array}$ & 48 & PT. Mandom Indonesia Tbk \\
\hline 24 & $\begin{array}{l}\text { PT. Beton Jaya Manunggal } \\
\text { Tbk }\end{array}$ & 49 & PT. Musthika Ratu Tbk \\
\hline 25 & PT. Citra Tubindo Tbk & 50 & PT. Unilever Indonesia Tbk \\
\hline
\end{tabular}

Sumber: Indonesian Capital Market Directory

Pengolahan Data

Uji Normalitas Data

Hasil pengujian normalitas data

dengan

menggunakan kolmogorov-smirnov

ditunjukkan pada tabel berikut ini:

Tabel 2

Hasil Uji Kolmogorov-Smirnov I

\begin{tabular}{|c|c|c|c|}
\hline Variabel & $\begin{array}{c}\text { Nilai } \\
\text { Sig. }\end{array}$ & $\begin{array}{c}\text { Sig. } \\
\mathbf{5 \%}\end{array}$ & Kesimpulan \\
\hline $\begin{array}{c}\text { Unstandardized } \\
\text { Residual }\end{array}$ & 0,013 & 0,05 & $\begin{array}{c}\text { Tidak berdistribusi } \\
\text { normal }\end{array}$ \\
\hline
\end{tabular}

Sumber: Hasil pengolahan data (lampiran)

Dari hasil pengujian diatas, diketahui nilai signifikansi lebih kecil dari taraf signifikansi yaitu 0,05 . Untuk menormalkan distribusi, maka dilakukan transformasi data dalam bentuk $L N$
(Logaritma Natural). Hasil pengujian normalitas data dengan menggunakan uji kolmogorovsmirnov setelah transformasi data dapat ditunjukkan pada tabel berikut ini: 
Tabel 3

Hasil Uji Kolmogorov-Smirnov II

\begin{tabular}{|c|c|c|c|}
\hline Variabel & $\begin{array}{c}\text { Nilai } \\
\text { Sig. }\end{array}$ & $\begin{array}{c}\text { Sig. } \\
\mathbf{5 \%}\end{array}$ & Kesimpulan \\
\hline $\begin{array}{c}\text { Unstandardized } \\
\text { Residual }\end{array}$ & 0,834 & 0,05 & $\begin{array}{c}\text { Berdistribusi } \\
\text { normal }\end{array}$ \\
\hline
\end{tabular}

Sumber: Hasil pengolahan data (lampiran)

Dari tabel 4.4 diatas menunjukkan bahwa variabel dependen dan variabel independen telah berdistribusi normal. Hal ini ditunjukkan dengan nilai signifikansi yang lebih besar dari taraf signifikansi yaitu 0,05. Dengan demikian dapat disimpulkan bahwa data tersebut berdistribusi normal.

\section{Uji Autokorelasi}

Uji autokorelasi digunakan untuk mendeteksi adanya korelasi internal diantara anggota-anggota dari serangkaian pengamatan yang tersusun dalam rangkaian ruang dan waktu. Untuk mendeteksi adanya autokorelasi dapat dilihat dari nilai Durbin-Watson.

\section{Tabel 4}

Hasil Uji Autokorelasi

\begin{tabular}{|c|c|c|c|}
\hline Model & Nilai DW & Kriteria & Kesimpulan \\
\hline $\mathrm{I}$ & 1,736 & \multirow{2}{*}{$\begin{array}{c}-2<\mathrm{DW} \\
<+2\end{array}$} & $\begin{array}{c}\text { Tidak ada } \\
\text { autokorelasi }\end{array}$ \\
\hline II & 1,379 & & $\begin{array}{c}\text { Tidak ada } \\
\text { autokorelasi }\end{array}$ \\
\hline
\end{tabular}

Sumber: data primer diolah, 2010

Tabel 4.5 menjelaskan bahwa nilai DW hitung berada antara -2 sampai +2. Hal ini menunjukan bahwa tidak ada autokorelasi dalam model regresi tersebut. 


\section{Uji Multikolinearitas}

Hasil pengujian multikolinearitas ditunjukkan dalam tabel berikut ini:

Tabel 5

Hasil Uji Multikolinearitas

\begin{tabular}{|c|c|c|c|c|c|}
\hline \multirow{2}{*}{ Variabel } & \multicolumn{2}{|c|}{ I } & \multicolumn{2}{c|}{ II (Tranformasi) } & \multirow{2}{*}{ Kesimpulan } \\
\cline { 2 - 5 } & Tolerance & VIF & Tolerance & VIF & Tidak terjadi \\
\hline EVA & .985 & 1.016 & .795 & 1.258 & $\begin{array}{c}\text { Tiltikolinearitas } \\
\text { muA }\end{array}$ \\
\hline ROE & .167 & 5.988 & .168 & 5.939 & $\begin{array}{c}\text { Tidak terjadi } \\
\text { multikolinearitas }\end{array}$ \\
\hline & 6.020 & .183 & 5.460 & $\begin{array}{c}\text { Tidak terjadi } \\
\text { multikolinearitas }\end{array}$ \\
\hline
\end{tabular}

Sumber: Hasil pengolahan data (lampiran)

Dari tabel 4.6. diatas, hasil nilai tolerance untuk semua variabel independen bernilai lebih besar dari 0,1 dan nilai VIF bernilai kurang dari 10 (regresi I maupun regresi II setelah ditransformasi data), maka dapat disimpulkan bahwa dalam model regresi tidak terdapat gejala multikolinearitas.

\section{Uji Heteroskedastisitas}

\section{Tabel 6}

Hasil Uji Heterokedastisitas

\begin{tabular}{|c|c|c|c|}
\hline \multirow{2}{*}{ Variabel } & \multicolumn{2}{|c|}{ Model II } & \multirow{2}{*}{ Kesimpulan } \\
\hline & $t_{\text {hitung }}$ & $p$ & \\
\hline EVA & 1.240 & .225 & $\begin{array}{l}\text { Tidak Terjadi } \\
\text { Heterokedastisitas }\end{array}$ \\
\hline ROE & .267 & .791 & $\begin{array}{l}\text { Tidak Terjadi } \\
\text { Heterokedastisitas }\end{array}$ \\
\hline ROA & -.144 & .887 & $\begin{array}{l}\text { Tidak Terjadi } \\
\text { Heterokedastisitas }\end{array}$ \\
\hline
\end{tabular}

\section{Sumber: data primer diolah 2011}

Hasil uji heteroskedastisitas yang telah dilakukan pengolahan data dengan bantuan SPSS pada tabel di atas, maka diketahui bahwa hasil pada model I variabel ROA memiliki nilai $\mathrm{p}<0,05$ yang 
berarti ROA mengalami gejala (masalah) heteroskedastisitas.

Setelah data ditranformasi, hasil pengujian menunjukkan bahwa ketiga variabel yang diteliti tidak ada yang memiliki nilai probabilitas < 0,05, maka dapat disimpulkan bahwa dalam model regresi ini standar error (e) tidak mengalami heteroskedastisitas.

gejala Pengujian Hipotesis

Persamaan regresi yang digunakan untuk melihat pengaruh Economic Value Added, Return On Asset dan Return On Equity terhadap return saham adalah sebagai berikut:

$$
\mathrm{Y}=a_{0}+\beta_{1} E V A+\beta_{2} R O A+\beta_{3} R O E+\mu
$$

Karena variabel independen yaitu Economic Value Added, Return On Asset dan Return On Equity dan variabel dependen yaitu return tidak berdistribusi normal, maka dalam penelitian ini terjadi perubahan persamaan regresi baik variabel independen maupun variabel dependen, karena penormalan data dilakukan dengan mentransformasi data dalam bentuk lain. Sehingga persamaan regresinya menjadi sebagai berikut:

\section{LNRETURN $=a_{0}+\beta_{1} L N E V A+\beta_{2} L N R O A+\beta_{3} L N R O E+\mu$}

Hasil analisis regresi untuk pengujian, dapat dilihat dalam tabel berikut ini:

TABEL 7

HASIL ANALISIS REGRESI

\begin{tabular}{lrrrr}
\hline \hline \multicolumn{1}{c}{ Variabel } & Koefisien & \multicolumn{1}{c}{ Std.Error } & \multicolumn{1}{c}{$\mathrm{t}$} & \multicolumn{1}{c}{ Sig. } \\
\hline \hline (konstanta) & 1.176 & 1.462 & .804 & .428 \\
LNEVA & -.158 & .093 & -1.699 & .100 \\
LNROA & -.246 & .910 & -.270 & .789 \\
LNROE & .370 & .917 & .404 & .689 \\
\cline { 2 - 5 } R Square & & $: 0,109$ & & \\
Std. Error of The Estimate & $: 1,162$ & & \\
F & $: 1,226$ & & \\
F (Sig.) & $: 0,317$ & & \\
Variabel Dependen & $:$ LNRETURN & & \\
\hline \hline
\end{tabular}

Sumber : Hasil olahan data (lampiran) 
Pengujian Koefisien Regresi secara Bersama-sama (Uji f)

Hasil uji hipotesis dan regresi dari tabel 7 diperoleh nilai $F_{\text {hitung }}$ sebesar 1,226 dengan tingkat signifikansi 0,317. Karena nilai signifikansi $\mathrm{F}$ lebih besar dari 0,05 maka disimpulkan tidak ada pengaruh simultan antara variabel Economic Value Added (EVA), Return on Assets (ROA), Return on Equity (ROE) terhadap Return Saham.

Pengujian Koefisien Regresi secara Parsial (Uji t)

Variabel EVA memiliki tingkat signifikansi lebih dari 0,05 yaitu sebesar 0,100. Dengan tingkat signifikansi 0,100 yang lebih besar dari 0,05 disimpulkan bahwa secara parsial Economic Value Added (EVA) tidak berpengaruh terhadap Return Saham perusahaan.

Variabel ROA memiliki tingkat signifikansi lebih besar dari 0,05 yaitu sebesar 0,789. Dengan tingkat signifikansi 0,789 lebih besar dari 0,05 disimpulkan bahwa secara parsial Return on Asset tidak berpengaruh terhadap Return Saham perusahaan.

Variabel ROE memiliki tingkat signifikansi lebih dari 0,05 yaitu sebesar 0,689. Dengan tingkat signifikansi sebesar 0,689 yang lebih besar dari 0,05 disimpulkan bahwa secara parsial Return on Equity (ROE) tidak berpengaruh terhadap Return Saham perusahaan.

Uji Koefisien Determinasi $\left(R^{2}\right)$

Hasil uji hipotesis dan regresi dari tabel 7 diperoleh nilai $\mathrm{R}^{2}$ sebesar 0,109 atau 10,9\%. Hal ini menunjukan bahwa 10,9\% dari nilai variabel dependen yaitu Return Saham dapat dijelaskan oleh Economic Value Added (EVA), Return on Assets (ROA) dan Return on Equity (ROE) sedangkan sisa nilai variabel dependen yaitu sebesar $89,1 \%$ tidak dapat dijelaskan oleh persamaan regresi atau dipengaruhi oleh faktor lain yang tidak termasuk dalam model analisis.

\section{Pembahasan Hasil Penelitian}

Dari hasil perhitungan diperoleh hasil persamaan regresi pertama seperti dibawah ini:

\section{LNRETURN $1.176=-0,158$ LNEVA - 0,246 LNROA + 0,370 LNROE}

Pada pengamatan tahun 2006 sampai 2008 variabel Economic
Value Added

(EVA)

berpengaruh signifikan tidak secara 
parsial, artinya variabel ini mempengaruhi Return Saham (100 $>0,05)$. Selain itu tanda yang dihasilkan pada koefesien regresi menunjukan hubungan negatif 0,158 , artinya setiap peningkatan Return on Asset sebesar 0,100 maka Return Saham perusahaan akan menurunkan sebesar 0,158 dengan asumsi variabel lain konstan.

Dari hasil perhitungan variabel ROA (Return on Asset) tidak signifikan pada taraf 0,05. hasil penelitian ini menunjukan variabel ROA pada perusahaan manufaktur tidak mempunyai pengaruh yang signifikan terhadap Return Saham perusahaan. Hasil persamaan regresi menunjukan bahwa ROA mempunyai arah koefisien regresi yang negative dengan Return Saham perusahaan

\section{PENUTUP}

\section{Kesimpulan}

1. Economic Value Added (EVA) tidak berpengaruh signifikan terhadap return saham $(p>$ $0,05)$, sehingga penurunan Economic Value Added (EVA) belum dapat mempengaruhi return saham.

2. Return On Asset tidak berpengaruh signifikan terhadap return saham ( $p>0,05)$, sehingga penurunan Return On sebesar 0,246. Artinya setiap peningkatan Return on Asset sebesar 0,789 maka Return Saham perusahaan akan menurunkan sebesar 0,246 dengan asumsi variabel lain konstan.

Dari hasil perhitungan uji $t$ variabel Return On Equity (ROE) tidak berpengaruh terhadap Return Saham perusahaan, karena nilai signifikansinya diatas 0,05 yaitu sebesar 0,689. Hasil persamaan regresi menunjukan bahwa ROE mempunyai arah koefisien regresi yang negative dengan Return Saham perusahaan sebesar 0,370. Artinya setiap peningkatan Return On Equity sebesar maka Return Saham perusahaan akan meningkatkan sebesar 0,370 dengan asumsi variabel lain konstan.

Asset belum dapat menaikkan return saham.

3. Return On Equity tidak berpengaruh signifikan terhadap return saham ( $p>0,05)$, sehingga kenaikan Return On Equity belum dapat mempengaruhi return saham. 


\section{Saran}

Hasil penelitian ini diharapkan dapat memberi masukan bagi investor dalam melakukan invetasi saham dengan tidak melihat kondisi perusahaan melalui rasio keuangan, khususnya melalui rasio EVA, ROA dan ROE tapi dengan rasio lain sebagai penentu investasi.

\section{DAFTAR PUSTAKA}

Bani, Wibowo Lucky. 2005. Pengaruh Economic Value Added dan Profitabilitas Perusahaan Terhadap Return Pemegang Saham. Skripsi Fakultas Ekonomi Universitas Islam Indonesia. Yogyakarta

Biddle, Gary C. 1998. Does EVA® Beat Earnings? Evidence on Associations With Stock Returns and Firm Values. School of Business Administration, University of Washington, Seattle, US.

Brigham, Eugene $F$ dan Joel $F$. Houston. 2001. Manajemen Keuangan. Jakarta: Erlangga.

Ghozali, Imam. 2002. Aplikasi Analisis Multivariate dengan Program SPSS. Semarang: Badan Penerbit Universitas Diponegoro.
Gujarati. 1995. Ekonometrika Dasar. Jakarta: Erlangga.

Husnan. 1993. Analisis Laporan Keuangan. Edisi Pertama. Yogyakarta: YKPN.

Husnan. 2001. Manajemen Keuangan. Edisi Pertama. Yogyakarta: YKPN.

Husnan, Suad dan Enny Pudjiastuti. 2002. Dasar-dasar Manajemen Keuangan. Edisi ketiga. Yogyakarta: YKPN.

Jogiyanto. 2000. Teori Portofolio dan Analisis Investasi. Edisi kedua. Yogyakarta: BPFE UGM.

Octora, Yuliana, Petrolina. 2003. Pengaruh Roa dan EVA terhadap Tingkat Pengembalian Saham (Rate Of Stock Return). Jakarta.

Rahayu, Mariana Sri. 2007. Analisis Pengaruh EVA Dan MVA Terhadap Return Saham pada Perusahaan Manufaktur Di Bursa Efek Jakarta. Skripsi Fakultas Ekonomi Universitas Islam Indonesia Yogyakarta.

Santoso, Singgih. 2003. Buku latihan SPSS Statistik Non Parametrik. PT Elex Media Komputindo, Jakarta. 
Dewi, Saptorini Kartika.2004. Pengaruh Economic Value Added (EVA) dan Rasio Profitabilitas Terhadap Perubahan Harga Saham Perusahaan Manufaktur Di Bursa Efek Jakarta. Skripsi S-1 UNS.

Sartono, R. Agus. 2003. Manajemen Keuangan Internasional. Edisi Pertama. BPFE, Yogyakarta.

Sasongko, Noer dan Nila

Wulandari. 2006. Pengaruh EVA dan Rasio-Rasio Profitabilitas terhadap Harga
Saham. Empirika, Vol. 19 (1): 64-80.

Yuniawan, Fandi. 2006. Analisis Pengaruh Penilaian Kinerja dengan ROI, ROE, OCF, dan EVA Terhadap Rate Of Return Pada Perusahaan Manufaktur di BEJ. Skripsi Fakultas Ekonomi Universitas Islam Indonesia Yogyakarta. 